Article

\title{
Crisis-Induced Leadership: Exploring the Role of the EU Commission in the EU-Jordan Compact
}

\author{
Karin Vaagland ${ }^{1,2}$ \\ ${ }^{1}$ FAFO-Institute for Labour and Social Research, Norway; E-Mail: kav@fafo.no \\ 2 Department of Political Science, University of Oslo, Norway
}

Submitted: 28 January 2021 | Accepted: 17 June 2021 | Published: 30 July 2021

\begin{abstract}
The EU-Jordan Compact (hereafter Compact) has been identified as being a groundbreaking, comprehensive approach to global refugee protection. Thus far, research on this underexplored case has mainly focused on the effects of the Compact. The policy process leading to the adoption of the Compact, as well as the motivations of the EU (i.e., the main donor), remain blackboxed. This article explores how the migration crisis affected the EU Commission's ability to create coordinated, strategic action in external policy. It does so by tracing the internal EU negotiations and developing a causal model that explains how the Commission could overcome silos and efficiently draft a policy proposal linking the issues of migration and trade. The analysis is based on 13 original in-depth interviews with EU representatives. The article contributes to crisisification theory by presenting a mechanism that explains how the Commission can make use of crises. The Commission created cohesion by reframing the crisis, identifying the relevant policy tools with which to address it, and by reframing the responsibilities of the relevant directorate-general. Furthermore, by utilizing the urgency of the crisis, the Commission enabled rapid policy drafting and created an explicit linkage between refugee policy and trade policy. This linkage provided the member states with the motivation to adopt the proposal as a solution to the ongoing migration crisis.
\end{abstract}

\section{Keywords}

crisis management; crisisification; European Union; foreign policy; international negotiation; Jordan; migration policy; refugee

\section{Issue}

This article is part of the issue "Resilient Institutions: The Impact of Rule Change on Policy Outputs in European Union Decision-Making Processes" edited by Ariadna Ripoll Servent (University of Salzburg, Austria) and Angela Tacea (Vrije Universiteit Brussel, Belgium).

(C) 2021 by the author; licensee Cogitatio (Lisbon, Portugal). This article is licensed under a Creative Commons Attribution 4.0 International License (CC BY).

\section{Introduction}

In 2015, the number of refugees entering Europe surged to over one million. In July 2016, the EU-Jordan Compact (hereinafter referred to as the Compact) was signed to provide the refugee-hosting state of Jordan with economic support and trade benefits. The Compact is recognized as being a groundbreaking and 'holistic' idea because of its innovative use of trade concessions as a tool in refugee policy (Betts \& Collier, 2017; Temprano-Arroyo, 2018). It is even considered to be a relevant model that can be exported to other refugeehosting nations (Brandt \& Kirisci, 2019; Temprano-Arroyo,
2018). This article explains the actions of the units within the EU Commission (hereinafter referred to as the Commission) in the intra-institutional negotiations, thus unpacking how the Compact was created and why it was adopted. The EU has been criticized for not coordinating external action across policy fields (i.e., Börzel \& Risse, 2004; Gebhard, 2011; Monar, 2015; Wolff, 2008). A lack of coordination has been explicitly demonstrated in the case of external migration and trade policy (Jurje \& Lavenex, 2014). I argue that the external relations units within the Commission along with the External Action Service leveraged the migration crisis to increase their influence within the Commission by arguing that trade concessions 
were the most appropriate measure and by reframing the responsibilities of the directorate-general (DG) for Trade, and furthermore that they created interest alignment with the member states through issue-linkage. Building on and further expanding crisisification theory (Rhinard, 2019), the article demonstrates how actors utilized the migration crisis to overcome internal silos and create a rapid policy response. The study has relevance for EU external policies more broadly, as it contributes to models of intra-institutional bargaining and shows how actors, through the reframing of issues and responsibilities, can contribute to changing the position of a powerful and conservative actor such as the DG for Trade (McKenzie \& Maissner, 2017, p. 837; Sicurelli, 2015).

The Compact is a bilateral agreement between the Hashemite Kingdom of Jordan and the EU and its member states, adopted by the EU-Jordan Association Council in July 2016. According to Poli $(2020$, p. 83) it can be argued that the Compact is a legal hybrid because although the EU-Jordan Association Council has legally binding powers, their decision was only to recommend that the Compact be implemented. It was inspired by the UN Compact, but the EU launched its own Compact with stronger commitments using the more efficient policy tools at the EU's disposal (Betts \& Collier, 2017). The EU offered Jordan trade concessions aimed at increasing exports to Europe, contingent on Jordan providing Syrian refugees with access to their labor market (Council of the European Union, 2016). The Compact was negotiated at the height of the EU migration (management) crisis when migration was a highly contentious and politicized issue. The contribution of this article lies in its demonstration of how the Commission used the crisis to influence policy. Furthermore, this contribution relates to the Politics and Governance thematic issue on The Impact of Rule Change on Policy Outputs, by highlighting the effects that external shocks can have on the relative power of EU institutions and on policy output.

Research on the Compact has thus far been mostly limited to reports, many of them done on assignment for the Compact's main donors, i.e., the UN and the EU (e.g., Agulhas, 2019; Center for Global Development, 2017; Overseas Development Institute, 2018; Temprano-Arroyo, 2018). The exceptions include academic articles that focus on the (thus far disappointing) effects that the Compact has had on refugees' access to rights and the labor market (Gray Meral, 2020; Lenner \& Turner, 2018; Mencutek \& Nashwan, 2020; Turner, 2021). The policy process behind it has so far only been explored from the Jordanian side (Seeberg, 2020; Seeberg \& Zardo, 2020). Donor state engagement is identified as a key factor in the success of refugee compacts without explaining donor state involvement in Jordan (Gray Meral, 2020; Lenner \& Turner, 2018; Mencutek \& Nashwan, 2020). An exploration of the legal aspects of the Compact has been offered by Poli (2020). Although she hints that there may be pragmatic reasons for the hybrid format, she does not explain this (Poli, 2020, p. 83). Furthermore, she argues that the Compact is an example of the rising number of practical and informal agreements in the EU's external migration policy, which have negative consequences for the balance of power between the EU institutions as it undermines the role of the EU Parliament (Poli, 2020, p. 80). This article explains donor state involvement and sheds light on the crisis policy process that leads to such sui generis policy outcomes.

The article is structured as follows. Section 2 presents the driving forces behind the external dimension of the EU's migration policy, first from its emergence in the 1980s until the crisis, and then since the migration crisis. In Section 3, the causal model explaining how the migration crisis affected the Commission's ability to create the Compact is presented. In Section 4, the methodology behind the data collection is described. Section 5 presents the analysis, tracing the negotiations. Section 6 provides a summary of the empirical findings and a discussion of the theoretical implications of the case study.

\section{EU External Migration Policy}

\subsection{Before the Migration Crisis, 1980s-2014}

While the external dimension of migration policy has recently gained more interest, it is by no means a new phenomenon. Since the 1980s, the member states have increasingly collaborated with countries outside of the EU on issues of migration (Guiraudon, 2002). The external dimension of migration policy was officially embraced at the EU level in 1999 (Lavenex \& Kunz, 2008). At the Tampere European Council in 1999, the member states declared their ambition for a 'comprehensive approach' to migration, which they defined as addressing political, human rights, and development issues in countries and regions of origin and transit (European Council, 1999). However, a review of the literature reveals that the expressed will for a comprehensive approach failed to translate into policy and that there are two main explanations as to why. The first being that the comprehensive approach has been sidelined by a securitization approach pursued by actors in the member states who found less containing factors at the EU level and with the external dimension in their pursuit of policy goals (Boswell, 2003; Guiraudon, 2002; Lavenex, 2006, 2018). Law and order officials strategically moved migration discussions to the EU level where they faced less opposition from political parties and civil society than at the member state level (Guiraudon, 2002) and further on to the external dimension (Lavenex, 2006). They achieved this by framing migration as a security issue and linking it to other global security threats that demanded transnational solutions (Guiraudon, 2002, p. 260).

The second reason for the failure of the comprehensive approach is that the Commission has not been able to cooperate across issue areas to create and push for comprehensive policy proposals (Boswell, 2003; Jurje \& 
Lavenex, 2014). Immigration ministers favored security policies rather than policies that fall under the portfolio of development and foreign affairs officials because they wanted to limit migration without losing autonomy (Boswell, 2003, p. 626; Lavenex, 2006). This tension went both ways, as development and foreign affairs officials were not interested in having their policy field downgraded to merely being a tool for reducing migration (Boswell, 2003). At the Commission level, such tension resulted in resistance against integrating migration prevention goals into the EU's external policy (Boswell, 2003, p. 626). The EU's ability to create coordinated, strategic action in its external relations has been questioned (Börzel \& Risse, 2004; Gebhard, 2011; Jurje \& Lavenex, 2014; Monar, 2015; Wolff, 2008). An example of this is migration and trade policy. Jurje and Lavenex (2014) find that the EU has not leveraged its market power to push its migration agenda in trade negotiations. The content of EU trade agreements reflected the institutional setup of the EU rather than relevant aspects of the third country, such as the number of migrants (Jurje \& Lavenex, 2014). Jurje and Lavenex (2014) argue that international migration was characterized by competing frames that cut across bureaucratic divides, which made it difficult to find shared ideals. This article makes an important contribution because it demonstrates how the Commission was able to bridge migration and trade in external policy by reframing the crisis in Jordan as a developmental and economic issue and by reframing the responsibilities of the DG for Trade. This argument has implications for the broader literature on EU external policies that often use models of institutional bargaining and which emphasize the tension between actors that pursue values and those that pursue commercial interests (see, for example, Gstöhl \& Hanf, 2014; McKenzie \& Maissner, 2017; Meunier \& Nicolaïdis, 2006; Sicurelli, 2015).

\subsection{The Migration Crisis}

Migration and asylum policies have always been politically salient, but the events in 2015 and 2016 changed the dynamics of decision making as they became issues of "high level crisis governance" (Smeets \& Beach, 2020, p. 135). In one year, the EU received more than one million refugees and migrants, resulting in a political crisis in which the core principles of EU integration broke down (Zaun, 2018). In addition, the migration (management) crisis hit the EU's image as a human rights promoter, when more than three thousand refugees drowned on the journey toward European shores (International Organization for Migration, 2016). In response to the crisis, the EU attempted to limit migration by striking deals with countries outside of Europe. These agreements are sui generis and often informal, meaning that the European Parliament is left out of the decision-making process (Poli, 2020).

Examples of intergovernmental bargains include the agreements with Turkey, Lebanon, and with countries in
North Africa and the Sahel. The agreement with Turkey is an extreme example of a protection strategy, wherein the aim is to control the EU border and limit the inflow of refugees, rather than a comprehensive strategy, which would also address the reasons for secondary movement among refugees in Turkey. Several other, lesser-known strategic partnerships with third countries have been established since the migration crisis. Across North Africa and in the Sahel region, the EU train police forces, monitor border controls, and push for the criminalization of smuggling activities (Bøås, 2019). The Compact with Jordan is another example of a pragmatic bilateral agreement. However, it stands out because it provides a more comprehensive approach to the causes of migration by addressing issues such as job opportunities for refugees (Poli, 2020).

So far, the policy responses to the crisis have been understood as being driven by the European Council (Lavenex, 2018; Smeets \& Beach, 2020; Trauner \& Ripoll Servent, 2016). Because of the increased politicization of migration policy, the member states wanted to regain national control over the issue (Lavenex, 2018). This has been the main explanation of the rise in intergovernmental bargains between member states and third countries, and protectionist policies (Greenhill, 2016; Lavenex, 2018). This development underlined the relevance of theories such as postfunctionalism and new intergovernmentalism (e.g., Bickerton et al., 2015; Hooghe \& Marks, 2018; Kleine \& Pollack, 2018; Schmidt, 2018; Smeets \& Zaun, 2020), which both share the idea that a transition of power and influence has taken place, i.e., from the supranational level to the intergovernmental level. These explanations emphasize that with the rise of the European Council, the Commission and the European Parliament have been marginalized in EU policymaking. However, such accounts fail to explain how the Commission was able to shape external migration policy, as in the case of the EU-Jordan Compact.

\section{Explaining the Success of the Commission}

The policymaking literature theorizes how actors adapt to changing circumstances and how they utilize change to gain influence (Trauner \& Ripoll Servent, 2016, p. 1420). Indeed, changes in the decision-making arena can be caused not only by institutional change but also by external shocks (Håkansson, 2021; Kaunert, 2010a, 2010b; Ripoll Servent, 2019; Trauner \& Ripoll Servent, 2016). A decade involving several severe crises has affected EU decision-making procedures, and Rhinard (2019) describes a process of 'crisisification.' Crisisification of decision-making procedures involves "finding the next urgent event, prioritizing speed in decision-making, ushering in new constellations of concerned actors and emphasizing new narratives of what matters in European governance" (Rhinard, 2019, p. 617). A crisis in itself does not affect the influence of different actors, but it is a window of opportunity that 
can be leveraged by actors in different ways (Trauner \& Ripoll Servent, 2016). A two-stage process drives crisisification (see Figure 1): The first stage takes place in the urgent aftermath of a crisis, wherein there is a demand for a political response, i.e., a 'call for action,' to which symbolic commitments by member states are often the first response (Rhinard, 2019). In the second stage, such commitments are leveraged by the Commission to build momentum for policy change (Rhinard, 2019). In fact, Rhinard $(2019$, p. 622$)$ goes so far as to argue that when it comes to crisis-related responses the Council will support the Commission in virtually any policy area. However, exactly how the Commission can make use of the crisis dynamic is not explained. This article unpacks stage two of crisisification theory as it peers into the gray box (Figure 1).

I use process-tracing methodology, following the guidelines of Beach and Pedersen (2019), to trace the negotiations that led to the Compact. The case study unpacks the second stage of crisisification theory: how the Commission can build momentum for policy change following a call for action. It explains this as a fourstep process, wherein cohesion is created within the Commission and the approval of member states is achieved. The four steps of the mechanism are presented in Figure 2. The Commission was able to leverage the crisis to act as a cohesive actor by reframing the crisis (Step 1) and identifying the appropriate tools, and by reframing the responsibilities of the directorates-general responsible for those tools (Step 2). Furthermore, the Commission was able to efficiently draft a policy proposal covering a broad set of issues by leveraging the urgency of the crisis to assemble a cross-sectoral working group (Step 3). Issue-linkage enabled the Commission to gain the approval of the member states by presenting them with policy solutions to issues made high-priority by the crisis (Step 4). The operationalization of the mechanism is presented in the Supplementary File, which also includes an evaluation of the strength of the data for each step of the mechanism.

\subsection{Reframing}

For a crisis to be converted into a policy response, double framing is required: First, a situation needs to be identified as a crisis; second, the nature and character of the crisis need to be specified (Voltolini et al., 2020, p. 620). The first stage of crisisification explains that member states will often respond urgently to what they perceive to be a crisis and ask for action. I argue that the Commission leadership can build on this request and specify the nature and character of the crisis (Step 1). For example, they can argue that it is a humanitarian or developmental issue, instead of a security issue. Through such reframing, the Commission can argue for the use of alternative policy tools such as humanitarian aid or trade policy as appropriate measures with which to address the crisis.

Furthermore, a crisis can be used to challenge the perceived appropriateness of existing normative frames such as perceived roles and responsibilities. I argue that the Commission leadership can exploit a crisis to expand an institution's understanding of its responsibilities (Step 2). For example, the terrorist attacks of 9/11 were used to reframe the EU as an actor in 'high politics' (den Boer \& Monar, 2002). Through reframing, the Commission leadership can advocate for the use of policy tools governed by one directorate-general on issues administered by another. In this case, the Commission leadership wanted to use trade concessions as a tool in refugee policy. Such policy proposals can be further legitimized by appealing to the EU as a 'Union of values' (Lavenex, 2018), making opposition more difficult.

\subsection{Issue-Linkage}

The embedded ways of working that are considered to be appropriate can be challenged in an urgent setting, and the Commission can implement administrative reforms to improve its efficiency in response to calls to 'do something' (Rhinard, 2019). I argue that this creates opportunities for establishing new informal working structures
Crisisification stage 1

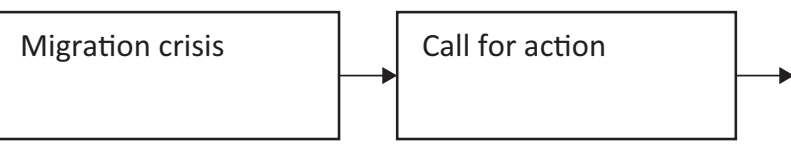

Crisisification stage 2

Commission

leverages momentum
Policy change

Figure 1. Crisisification theory illustrated. 


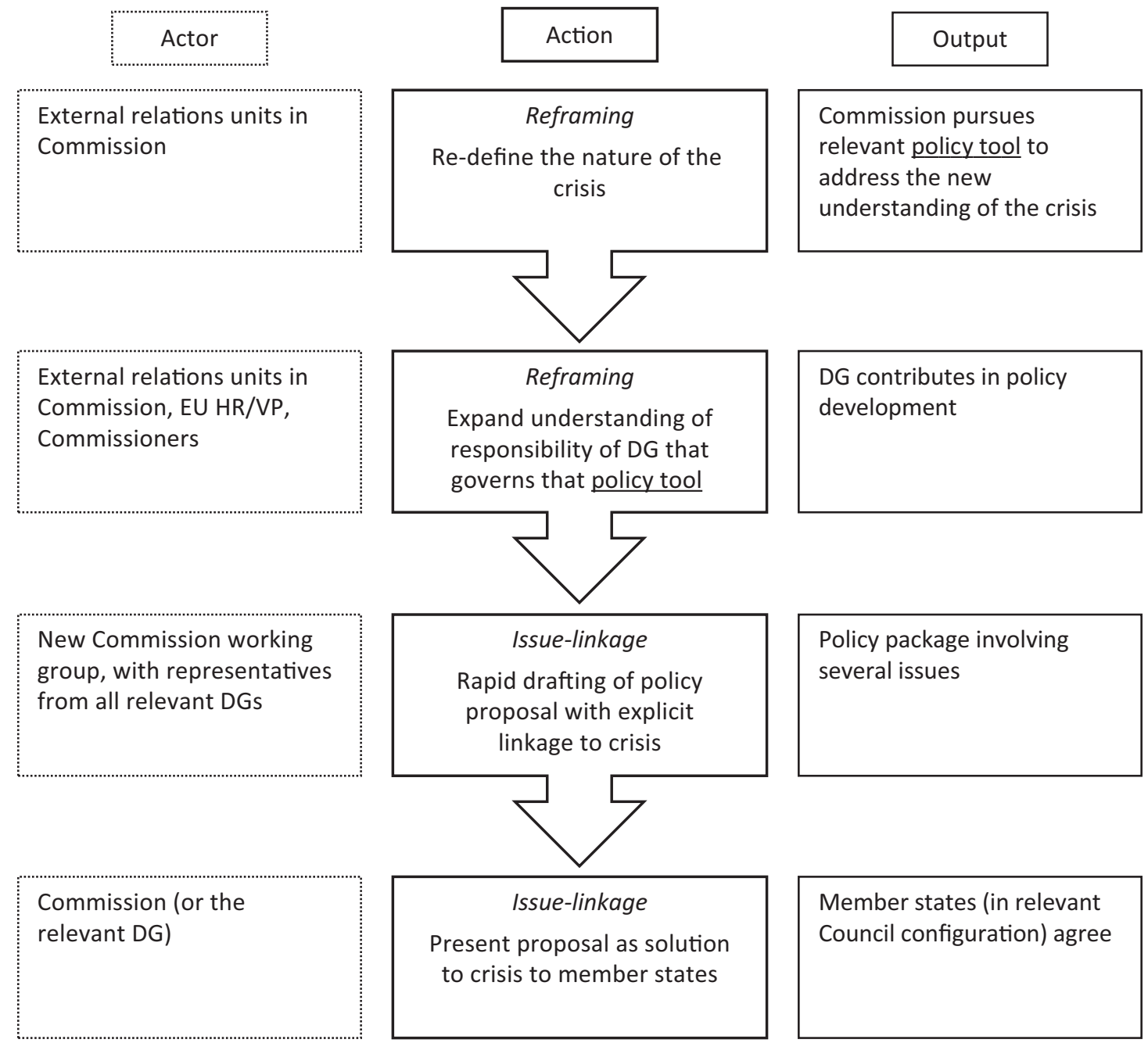

Figure 2. Four-step causal model explaining how the Commission leveraged the refugee crisis.

that cut across existing silos, such as a working group or a taskforce (Step 3). Lewis (2010) argues that a high degree of insulation, a broad scope of issues, and intensive interaction all promote cooperative negotiations between member states in the Council (of Ministers). His theory is here transferred to the Commission to argue how cross-sectoral cooperation can be cultivated to achieve efficient policy drafting across issue areas. This influences the efficiency of the technical drafting of a proposal, which happens at a lower level of the Commission. However, cohesiveness in the Commission is a necessary condition for the working group to be successful. Lower-ranking desk officers who take part in the technical drafting do not have the freedom to go beyond their responsibilities which are defined by others higher up in the system.

If the Commission does achieve rapid drafting of a policy solution involving several issue areas, I argue that it increases the likelihood of a policy package being adopted by the member states (Step 4). Through linkage, the Commission can include high-priority issues for the member states in their proposal. However, for this to be successful the Commission needs to be quick in the draft- ing so that they can leverage the pressure that member states experience during an urgent crisis. This pressure is what makes the issue a priority for the member states and makes issue-linkage effective.

\section{Data}

The analysis is based on the main document stipulating the Compact, i.e., the annex to the 2016-2018 EU-Jordan Partnership Priorities and Compact (Council of the European Union, 2016), as well as on original interviews with EU representatives with knowledge of the negotiations. The interviews were conducted between March and September 2020, online or via telephone. The interviews lasted between 50 and 90 minutes. They were semi-structured (following an interview guide developed after document analysis of the agreement). Fourteen EU representatives were identified by means of snowball sampling. In the final round of interviews, the participants referred me only to people whom I had already interviewed, signaling that I had already identified the key individuals who were involved. Only one interviewee declined because of 
limited time, producing a total number of 13 interviews. The interviewees represent most of the relevant Commission units that are likely to have been involved in the process. Interviews were conducted with representatives from the DGs for: Trade, Neighborhood and Enlargement Negotiations (NEAR), Migration and Home Affairs, European Civil Protection and Humanitarian Aid Operations (ECHO), and Economic and Financial Affairs (ECFIN). A member of a Commissioner's cabinet also participated. In addition, representatives from the European External Action Service (EEAS) and from the Amman delegation also participated.

The participants include desk officers, directors, and a cabinet member. Eight of the interviewees were active participants in the negotiations or the drafting, one interviewee was active in the concluding phase, and four were active in the implementation of the Compact. All of them possessed knowledge of what took place during the negotiations, either through direct participation or through accounts given to them by their colleagues who had participated. Although there are obvious advantages of first-hand accounts, second-hand accounts can (arguably) be less at risk of social desirability bias because they have less inclination to exaggerate or to describe the participants in an advantageous way. Accounts that support the steps of the mechanism should be confirmed by several sources (see Table 1 in the Supplementary File for operationalization). By including interviewees from different units and at different levels, and by including participants with first-hand knowledge as well as their colleagues with second-hand knowledge, there is some width in the data collection to allow for triangulation.

All interviewees requested anonymity so that they could speak freely, thus providing me with better data. To ensure this, all interviewees are referred to by the numbers 1 to 13 . Because it was a relatively small group of people participating in the policymaking process, revealing their institution or position in the publication might jeopardize their anonymity. I have, however, borne in mind their position and institution while evaluating the strength of the data (see Table 1 in the Supplementary File).

\section{Tracing the Negotiations}

\subsection{Reframing}

Jordan had long wanted to increase its exports to Europe and had formally requested a relaxation of the rules of origin before the Syria conflict began. This demand was rejected by the Commission partly because DG Trade was reluctant to grant just one country in the neighborhood special conditions (Interviews 3, 5, 7, 13). The first two steps of the mechanism explain how units within the Commission were able to leverage the crisis to create internal unity, which was necessary to successfully have the Compact adopted. The first entails a reframing of the nature of the crisis. DG NEAR and the EEAS had very similar understandings of the situation in Jordan. Several of the interviewees from DG NEAR and the EEAS underlined that the dire economic situation in Jordan already existed before the refugee crisis, as a result of the many years of conflict and a lack of stability in the region (Interviews 1, 10). They also argued that the additional burden of hosting 650,000 refugees had made the situation worse. Furthermore, there are accounts that support the notion that economic issues in Jordan were their main motivation for the Compact: "Obviously, the narratives and the response to the Syrian crisis contributed to the discourse around development assistance in the southern Mediterranean, but I don't think that they were the main driver in this case" (Interview 10). Another interviewee referred to the importance of having a stable partner in the region, one that is a good ally for the EU in geopolitics, and further stated:

All these factors make it very important for us that Jordan remains there as a stable country, so this is really the long-term interest. It would be tragic if Jordan were to fall, and everything is targeted towards the objective of making them sustainable in the long term. (Interview 1)

Across the different DGs in Commission, they all perceived the situation in Jordan to be an urgent crisis; furthermore, the DG NEAR and the EEAS considered the crisis to be economic in nature and that it was further exasperated by the refugee situation. They argued that the crisis was economic in nature and reframed it from a refugee issue to an economic and development issue. Representatives from DG ECFIN expressed that they understood the crisis in Jordan to be an economic one (Interview 3) and this explains why also they were in favor of granting Jordan trade preferences. DG ECHO wanted to better the livelihoods of refugees living in Jordan, and so they welcomed policies that could provide jobs for refugees (Interview 11). By successfully reframing the crisis as an economic and developmental one, the interests and understandings of some of the different units in the Commission were aligned.

Furthermore, by framing the crisis as a developmental and humanitarian one, trade policy was made an appropriate measure with which to respond to the crisis. This meant that DG for Trade, i.e., the DG governing EU trade policy, became a key actor when moving forward in the negotiations. In the initial inter-service consultations in the Commission, DG ECFIN, DG NEAR, and DG ECHO were all very much in favor of providing trade preferences linked to assisting the refugees in Jordan (Interview 3). DG for Migration and Home Affairs was not much involved, because so few refugees from Jordan travelled onwards towards Europe, they were not stakeholders in the process (Interview 8). However, DG for Trade was initially reluctant. This leads to the second step of the mechanism, which entails getting the support of the relevant DG. 
DG for Trade did not agree that external migration policy fell within their responsibilities. DG for Trade was described by several interviewees as being orthodox, mercantile, and working primarily for the protection of the economic interests of member states (Interviews 3, $6,10,13)$. Another perspective on this is that the DG for Trade was very sensitive and responsive to the member states' positions in trade policy because they regularly discussed it with them in the Trade Policy Committee. This means that the DG for Trade knew what the member states would, and would not, be able to accept. In order to get the DG for Trade to work toward the political goal set by the EEAS and DG NEAR, which was now a goal shared by other DGs in the Commission such as DG ECHO and DG ECFIN, tremendous pressure was placed on the DG for Trade to support the proposal (Interviews 4, 9, 13). The High Representative of the Union for Foreign Affairs and Security Policy, i.e., Federica Mogherini, and directors in both DG NEAR and the EEAS, as well as Trade Commissioner Cecilia Malmström were all pushing the DG. The United Kingdom was an important ally and advocate for Jordan and the Compact, with the British ambassador visiting a DG for Trade director to present trade concessions as a solution to the crisis in Jordan (Interviews 5, 7). This broad alliance of players from both within and outside the Commission argued that there was a sense of urgency because of the crisis and, furthermore, that trade policy was the relevant tool to use in order to resolve the crisis. This argumentation was effective in persuading the DG for Trade to expand their responsibilities and created unity in the Commission in the pursuit of the Compact. This confirms the second step of the mechanism. By February 2016, the DG for Trade was very much leading the policy process. They were chef de field in the negotiations within the Commission as well as vis-à-vis the member states in the Trade Policy Committee in the Council (Interviews 3, $7,13)$. One DG for Trade representative expressed that trade was considered the most appropriate solution:

Of course, helping Syrian refugees is a political objective, if I may put it that way, but it is a trade-related initiative contributing to a political objective because at that moment it was considered to be the most appropriate one.

One high-ranking official within the DG for Trade at the time explained this shift partly with the ambition of the DG for Trade to be responsible outside of their immediate issue area:

I thought that we had to demonstrate that [our DG] could be responsive to this kind of political and social situation, like the one that had been generated by the refugee crisis, and that it was, therefore, better that we were proactive and that we started from the beginning to try to explore solutions.
Even though the DG for Trade took ownership over the Compact, this does not necessarily signify a more permanent expansion of the DG's responsibilities to include migration issues. Interviewees from inside and outside of the DG for Trade did not believe that this signified a permanent shift in the understanding of their role (Interviews 4, 9, 13). The case does, however, demonstrate how DG NEAR and the EEAS were able to use the momentum of the crisis to create internal cohesion.

\subsection{Issue-Linkage}

Crisisification theory explains that a call for action by the member states will follow shortly after a crisis (Rhinard, 2019). In 2015, the Council asked the Commission and the EU delegation in Amman to do "anything possible" for the ongoing refugee crisis (Interview 5). This enabled the Commission to move forward with a rapid drafting of the policy proposal-step three of the mechanism. The call for action triggered a change in working structures, as a small working group was set up with members from the EU's Amman delegation, the EEAS, and technical expertise from the DG for Trade and DG NEAR (Interviews 5, 9, 13). The small working group engaged in cooperative negotiations by working in a separate and small group of people allowing a high level of trust, working on broad scopes of issues, and working very intensively over a short period. They succeeded in creating the first draft by October 2015. The draft was, in fact, written by a desk officer in the DG for Trade, which demonstrates the necessity of getting the DG to contribute to the policy process. Members of the working group described the process as being unique in that it was highly intensive, and they worked very closely together day and night. One member claimed that some did not last long there because of the pressure (Interview 9). Furthermore, they argued that it was the sense of urgency caused by the crisis enabled this new working structure (Interviews 3, 5). People who were not part of the initial negotiations supported the claim of how remarkably quick the development of the proposal was (Interview 2). The very novel idea was remarkably drafted within only a few months of the group being given the assignment.

In this working group, the novel idea of linking trade concessions to the employment of refugees was further developed from a vague idea into a highly technical policy proposal (Interview 2). In February 2016, at the London Syria Conference, the EU made their first public commitment to offering Jordan trade concessions contingent on Jordan granting work permits to Syrian refugees (Interview 3).

During the final phase of the negotiations, from February to July 2016, there were expectations that the EU would deliver on the commitments made to Jordan at the London Conference and to the Syrian refugees living in Jordan. The member states' refusal to receive more refugees provided further motivation to assist the refugee-hosting countries outside of the EU 
(Interviews 6, 9). The tragic number of deaths at sea further escalated domestic pressure for EU action (Interviews 1, 5). The final step of the mechanism involves convincing the member states to adopt the policy proposal. The Compact was not supported by all member states initially, but the crisis led to increased pressure for them to act:

Some member states initially were not terribly enthusiastic. They insisted that they could accept it because of the very special political situation and provided that there was a very strong linkage to refugees. (Interview 7)

DG for Trade was identified as a crucial advocate for the Compact. Because the DG for Trade benefits from a position as trusted experts in trade, and because trade is an exclusive competence of the Commission, they were able to push the member states to agree to the trade concessions (Interview 13). They achieved this by presenting projections for expected imports from Jordan indicating that there was little risk involved for any member states. The member states with large textile industries were particularly concerned because textile products would benefit from the trade preferences (Interview 2). The member states were also worried about other countries with larger economies, such as Morocco or Tunisia, asking for similar benefits. The DG for Trade drafted the agreement in such a way that the trade preferences only applied to businesses in Special Economic Zones in Jordan that employed a minimum share of refugees, ensuring that no other country would be able to ask for a similar agreement (Interviews 2, 7, 13). The important role the DG for Trade played in convincing the member states underlines the importance of internal cohesion within the Commission (Step 2 of the mechanism). Furthermore, the Commission realized that linking the migration crisis to their proposal was a clever way of motivating the member states to adopt the proposal:

2015 was, of course, the year of migration crisis for the EU, so there was a recognition that we did not want refugees to leave their countries of temporary residence bordering Syria. For me, it is quite a clever way of dealing with the issue and it would have been attractive to many people in the EU system and to many of the member states. (Interview 6)

This suggests that step four of the mechanism is present. Another participant noted how time-sensitive the proposal was, arguing that only a few months later, the discussions in Europe were completely different in nature and that there would have been little political will to prioritize aid to refugees outside of Europe (Interview 4). This demonstrates how important it is that the drafting (Step 3) be efficient for the mechanism to work. The European Parliament was not formally involved in the negotiations, but they were briefed on the proposal by the Commission (Interviews 3, 4). The Commission wanted to convince the Parliament that the Compact was necessary because they wanted to have as broad a coalition as possible to avoid any push back (Interviews 4, 5).

The sense of urgency that was necessary for the Commission to succeed in drafting and defending the Compact shed some light on the sui generis format of the Compact. The format was pragmatic in the sense that it ensured swift drafting and adoption. The EU-Jordan Association Council adopted the Compact in July 2016, but as pointed out by Poli (2020, p. 83), in the joint decision the parties only recommended implementation (EU-Jordan Association Council, 2016, p. 1). The phrasing of the implementation as a recommendation rather than something more binding reflected concerns on the Jordanian side regarding the granting of Syrians' access to work permits (Interviews 12, 13).

\section{Conclusion}

Through tracing the internal EU negotiations that led to the Compact, this article demonstrates the presence of a causal mechanism explaining how external relation units within the Commission and the EEAS can leverage a crisis to influence external EU policy. They argued that there was a dire economic situation in Jordan and that the additional burden of hosting 650,000 refugees had made the situation worse. This reframing of the refugee crisis meant that development assistance tools such as trade concessions became appropriate measures with which to address the situation. As trade policy is governed by the DG for Trade, pressure was put on the DG from a broad alliance of players including the Commissioner for Trade, the High Representative of the Union for Foreign Affairs and Security Policy, the EEAS, DG NEAR, DG ECHO, DG ECFIN, and the United Kingdom. The DG for Trade assumed this responsibility and went on to lead the negotiations internally as well as vis-à-vis the member states in the Trade Policy Committee in the Council. However, accounts suggest that this was a temporary expansion of responsibilities that may not be long-lived. The Commission set up a cross-sectoral working group that was tasked with the urgent assignment of creating a policy proposal for the Compact. The group efficiently created a highly technical proposal with explicit linkages between refugee policy and trade policy. This proposal was presented to the member states as an important solution to the ongoing migration (management) crisis that was playing out in Europe, and the member states accepted the proposal after being convinced by the DG for Trade. The conclusion of informal agreements with third countries such as the Compact with Jordan is not prohibited by EU law, but as Poli argues (2020, p. 80), it does have consequences for the balance of power between the EU institutions. This article has demonstrated how a crisis can be leveraged by actors in the Commission who aim to influence policy outcomes, and how this results in informal policy processes that do not 
include the European Parliament. In addition, this article has explained how reframing contributed to the DG for Trade assuming the role as a reluctant initiator of the Compact-this has implications for institutional bargaining models used to explain EU external policies more broadly, such as trade (Gstöhl \& Hanf, 2014; McKenzie \& Maissner, 2017; Sicurelli, 2015).

The causal mechanism presented in this article expands crisisification theory, which suggests that the Commission can make use of crises to influence policy (Rhinard, 2019). The mechanism described in this article explains only one of many processes that have contributed to the Compact. The roles of several important actors, such as the Jordanian government, the UN Refugee Agency, the United Kingdom, and the European Council, are not included in this study. Additional case studies on the Commission's role in external EU policies during crises are needed, as they could contribute to strengthening or revising the mechanism presented in this article.

Finally, this article provides important empirical findings on the negotiation process behind this hitherto under-researched Compact. If the Compact approach is to be replicated in other refugee-hosting nations, it is important to understand how it came about from the perspective of the main donor, i.e., the EU. Based on the empirical findings presented in this article, it is doubtful that a similar policy output will be replicated in the future. It is not likely that the DG for Trade will contribute to the same degree in future contexts, and it is doubtful that the member states will find themselves in an equally politicized crisis.

\section{Acknowledgments}

I am grateful to the editors of this thematic issue, for their guidance and encouragement. I would also like to thank the three anonymous reviewers for their constructive and insightful comments. This work was supported by the Norwegian Research Council.

\section{Conflict of Interests}

The author declares no conflict of interests.

\section{Supplementary Material}

Supplementary material for this article is available online in the format provided by the author (unedited).

\section{References}

Agulhas. (2019). Report monitoring and assessment framework for the Jordan Compact.

Beach, D., \& Pedersen, R. B. (2019). Process-tracing methods: Foundations and guidelines (2nd ed.). University of Michigan Press.

Betts, A., \& Collier, B. (2017). Refuge: Transforming a bro- ken refugee system. Penguin.

Bickerton, C. J., Hodson, D., \& Puetter, U. (2015). The new intergovernmentalism: European integration in the post-Maastricht era. Journal of Common Market Studies, 53(4), 703-722.

Bøås, M. (2019). EU migration management in the Sahel: Unintended consequences on the ground in Niger? Third World Quarterly. Advance online publication. https://doi.org/10.1080/01436597.2020.1784002

Börzel, T. A., \& Risse, T. (2004, October 4-5). One size fits all! EU policies for the promotion of human rights, democracy and the rule of law [Paper presentation]. Workshop on Democracy Promotion, Stanford, CA, USA.

Boswell, C. (2003). The 'external dimension' of EU immigration and asylum policy. International Affairs, 79(3), 619-638.

Brandt, J., \& Kirisci, K. (2019, February 9). Expert voices: EU-Turkey trade compact could benefit Syrian refugees. Axios. https://www.axios.com/euturkeytrade-compact-could-benefit-syrian-refugeeseef4bf56-153f-4288-87fc-9248eebd09bd.html

Center for Global Development. (2017). Refugee compacts: Addressing the crisis of protracted displacement (Final Report of the Forced Displacement and Development Study Group).

Council of the European Union. (2016). EU-Jordan partnership priorities and compact (Annex to Decision No. 01/2016 of the 12th EU-Jordan Association Council of June 10, 2017). European Union.

den Boer, M., \& Monar, J. (2002). Keynote article: 11 September and the challenge of global terrorism to the EU as a security actor. Journal of Common Market Studies, 40, 11-28.

EU-Jordan Association Council. (2016). Decision No 1/2016 of the EU-Jordan Association Council of 19 December 2016 agreeing on EU-Jordan partnership priorities (2016/2388).

European Council. (1999). Conclusions of the Presidency, 15-16 November. European Union.

Gebhard, C. (2011). Coherence. In C. Hill \& M. Smith (Eds.), International relations and the European Union (pp. 101-127). Oxford University Press.

Gray Meral, A. (2020). Assessing the Jordan Compact one year on: An opportunity or a barrier to better achieving refugees' right to work. Journal of Refugee Studies, 33(1), 42-61.

Greenhill, K. (2016). Open arms behind barred doors: Fear, hypocrisy and policy schizophrenia in the European migration crisis. European Law Journal, 22(3), 317-332.

Gstöhl, S., \& Hanf, D. (2014). The EU's post-Lisbon free trade agreements: Commercial interests in a changing constitutional context. European Law Journal, 20(6), 733-748.

Guiraudon, V. (2002). European integration and migration policy: Vertical policy-making as venue shopping. Journal of Common Market Studies, 38(2), 251-271. 
Håkansson, C. (2021). The European Commission's new role in EU security and defence cooperation: The case of the European Defence Fund. European Security. Advance online publication. https://doi.org/ 10.1080/09662839.2021.1906229

Hooghe, L., \& Marks, G. (2018). Cleavage theory meets Europe's crises: Lipset, Rokkan, and the transnational cleavage. Journal of European Public Policy, 25(1), 109-135.

International Organization for Migration. (2016). Missing migrants project (Mediterranean Update January 31, 2015).

Jurje, F., \& Lavenex, S. (2014). Trade agreements as venues for 'market power Europe'? The case of immigration policy. Journal of Common Market Studies, 52(2), 320-336.

Kaunert, C. (2010a). The area of freedom, security and justice in the Lisbon Treaty: Commission policy entrepreneurship? European Security, 19, 169-189.

Kaunert, C. (2010b). European internal security: Towards supranational governance? Manchester University Press.

Kleine, M., \& Pollack, M. (2018). Liberal intergovernmentalism and its critics. Journal of Common Market Studies, 56(7), 1493-1509.

Lavenex, S. (2006). Shifting up and out: The foreign policy of European immigration control. West European Politics, 29(2), 329-350.

Lavenex, S. (2018). 'Failing forward' towards which Europe? Organized hypocrisy in the common European asylum system. Journal of Common Market Studies, 56(5), 1195-1212.

Lavenex, S., \& Kunz, R. (2008). The migrationdevelopment nexus in EU external relations. European Integration, 30(3), 439-457.

Lenner, K., \& Turner, T. (2018). Making refugees work? The politics of integrating Syrian refugees into the labor market in Jordan. Middle East Critique, 28(1), 65-95.

Lewis, J. (2010). How institutional environments facilitate cooperative negotiation styles in EU decisionmaking. Journal of European Public Policy, 17(5), 648-664.

McKenzie, L., \& Maissner, K. (2017). Human rights: Conditionality in European Union trade negotiations: The case of the EU-Singapore FTA. Journal of Common Market Studies, 55(4), 832-849.

Mencutek, Z. S., \& Nashwan, A. J. (2020). Perceptions about the labor market integration of refugees: Evidences from Syrian refugees in Jordan. Journal of International Migration and Integration. Advance online publication. https://doi.org/10.1007/s12134020-00756-3

Meunier, S., \& Nicolaïdis, K. (2006). The European Union as a conflicted trade power. Journal of European Public Policy, 13(6), 906-925.

Monar, J. (2015). The EU as an international counterterrorism actor: Progress and constraints. Intelli- gence and National Security, 30(2/3), 333-356.

Overseas Development Institute. (2018). The Jordan Compact: Lessons learnt and implications for future refugee compacts (Policy Briefing).

Poli, S. (2020). the integration of migration concerns into EU external policies: Instruments, techniques and legal problems. European Papers, 5(1), 71-94.

Rhinard, M. (2019). The crisisification of policy-making in the European Union. Journal of Common Market Studies, 57(3), 616-633.

Ripoll Servent, A. (2019). Failing under the 'shadow of hierarchy': Explaining the role of the European Parliament in the EU's 'asylum crisis.' Journal of European Integration, 41(3), 293-310

Schmidt, V. A. (2018). Rethinking EU governance: From 'old' to 'new' approaches to who steers integration. Journal of Common Market Studies, 56(7), 1544-1561.

Seeberg, P. (2020). Syrian refugees in Jordan and their integration in the labour market: Jordanian migration diplomacy and EU incentives. Mediterranean Politics. Advance online publication. https://doi.org/ 10.1080/13629395.2020.1758452

Seeberg, P., \& Zardo, F. (2020). From mobility partnerships to migration compacts: Security implications of EU-Jordan relations and the informalization of migration governance. Journal of Ethnic and Migration Studies. Advance online publication. https://doi.org/ 10.1080/1369183X.2020.1851465

Sicurelli, D. (2015). The EU as a promoter of human rights in bilateral trade agreements: The case of the negotiations with Vietnam. Journal of Contemporary European Research, 11(2), 230-245.

Smeets, S., \& Beach, D. (2020). When success is an orphan: informal institutional governance and the EU-Turkey deal. West European Politics, 43(1), 129-158.

Smeets, S., \& Zaun, N. (2020). What is intergovernmental about the EU's '(new) intergovernmentalist' turn? Evidence from the Eurozone and asylum crises. West European Politics. Advance online publication. https://doi.org/10.1080/01402382.2020.1792203

Temprano-Arroyo, H. (2018). Promoting labour market integration of refugees with trade preferences: Beyond the EU-Jordan Compact (EUI RSCAS, 2018/42, EUI Working Paper). Migration Policy Centre.

Trauner, F., \& Ripoll Servent, A. (2016). The communitarization of the area of freedom, security and justice: Why institutional change does not translate into policy change. Journal of Common Market Studies, 54(6), 1417-1432.

Turner, L. (2021). Internal solidarity, external migration management: The EU pact and migration policy towards Jordan. In S. Carrera \& A. Geddes (Eds.), The EU pact on migration and asylum in light of the United Nations global compact on refugees (pp. 81-90). European University Institute.

Voltolini, B., Natorski, M., \& Hay, C. (2020). Introduction: 
The politicisation of permanent crisis in Europe. Journal of European Integration, 42(5), 609-624.

Wolff, S. (2008). Border management in the Mediterranean: Internal, external and ethical challenges. Cambridge Review of International Affairs, 21(2),
253-271.

Zaun, N. (2018). States as gatekeepers in EU asylum politics: Explaining the non-adoption of a refugee quota system. Journal of Common Market Studies, 56(1), 44-56.

\section{About the Author}

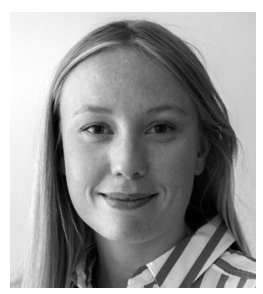

Karin Vaagland holds an MA in Political Science. She is a PhD Candidate at the Department of Political Science at the University of Oslo. Her PhD project is funded by the Research Council of Norway and is part of the FAFO-led project: European Management of Migration and Refugees (MARE). Her PhD research focuses on the policy processes and multilateral negotiations that shape the EU's external migration policies. 